\title{
使用経匼
}

\section{シリンジポンプのノイズによる人工呼吸器用 加温加湿器の異常加温に関する検討}

\section{はじめに}

人「呼吸器管理中の加温・加湿は必要不川久 であり, 加温加鼬器や人「鼻が一般的に使用さ れている，当センターでは，外気による温度低 下゙を防ぐための熱線を併用した，パスオーバー 方式の加温加湿器を使用している.この加温加 湿器の温度制御は，口元温度とチャンバー出门 の温度を測定し，設定された口元温度に制御す るデュアルサーボ方式であり，ヒーターの ON /OFF は電源の正弦波形を利用して制御してい る.

この加温加湿器が臨从使用中に簧常加温を起 こし, 11 元温度が $40^{\circ} \mathrm{C}$ を越え, 過温警報が作 動しているにも関わらず，更に加温を続け，尼 険な状態となった：今回，この異常加温に関す る検竐を行ったので郝告する。

\section{異常加温の状況}

当センター循環器病楝 CCUに年いて，1990 年12月～1991年 2 月にかけて 3 回の異常加温が 発生した. 発生状況は 3 回とも汪ほ同梯で，デ ィマンドフロータイプの人工呼吸器を使用して いた，加温加湿器は，この人「呼吸器の台本に 取り付忛らた $3 \mathrm{P}$ テーブルタッブを用いて， 非授地回路である瞬時特别非常用電源（傅電後

*埝玉県立小児医祭センターME室

$$
\begin{array}{ll}
* 2 & \text { 问 } \text { 心臟血管外科 } \\
& \text { 同 }
\end{array}
$$

（原稿受付日：1994年12月13日）
松茾晃*小池龍平* 古山義明* 中村 譲*2 鈴木美佐子*3

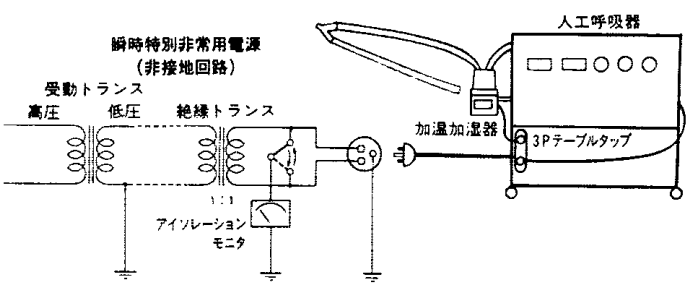

図 1 異常加温時の機器接続状況

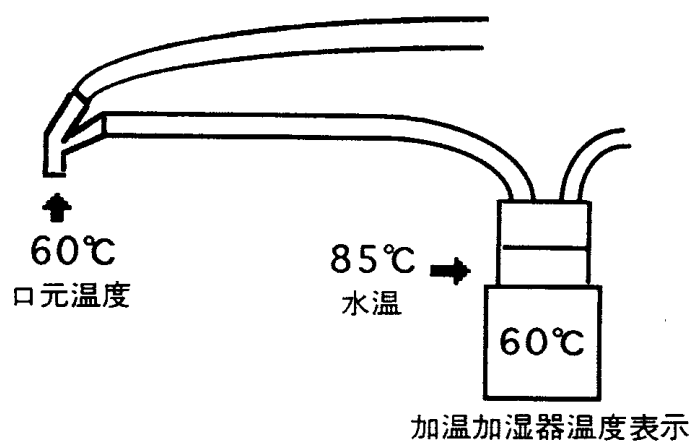

図 2 加温加湿器の異常状態

ほぼ膎時に作動する充電回路）に接続されてい た（図 1).

1 回目の発生状沉は，加温加湴器の過温警跟 が作動するといらことで，病棟よりME室に低 頼があった．加温加湿器の几元温度は $40^{\circ} \mathrm{C}$ に 上界し，過温警報が作動していた。このままテ スト肺により動作を続けると，渵温警報が作動 しているにもかかわらずロ元渭度は $60^{\circ} \mathrm{C} に$ 多し，チャンバー内の水渭は $85^{\circ} \mathrm{C}$ に束で進し

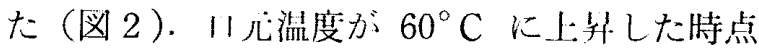
で伦隃と判断し動作を倧止:させたが，このまま 動作させていれば或にい元温度は上算したと考 えられる.この時の対応として，人「呼吸器の

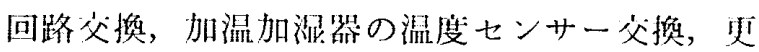




\section{( 34 ) 医器学 Vol. 65, No. 5 (1995)}

に, 同タイプの加温加湿器を 3 台交換したが同 様の状況が続いた.この時の電源電圧は $105 \mathrm{~V}$ と正常であった。

2 回目の現象は，1回目とほぼ同様であった が，原因追及には至らなかった。

3 回目の現象も $1 ， 2$ 回目とほぼ同様であっ たが, この時の対応として加温加湿器の使用電 源を, 瞬時特別非常用電源から非接地回路であ る一般非常用電源（停電後 40 秒程度で復㷌する 発電回路）に切り换えたところこの現象は停止 した. その後, 加温加湿器の使用電源を一般非 常用電源に統一することにより, 臨床での異常 加温は出現しなくなった。

\section{原因追求 I}

3 回目の発生時に打いて, 瞬時特別非常用電 源に原因があることが考えられたため，装日に 現象の再現を試みたところ異常加温は発生した. この時の電源電圧は, 変動性を見たが最大 139 $\mathrm{V}$ を示した。一方, 一般非常用電源は $105 \mathrm{~V}$ であった。また, 異常加温状態の加温加湿器の 消費電流は $1.1 \mathrm{~A}$ であり, 実際にヒーターが作 動していることを確認した。

瞬時特別非常用電源の電圧が $139 \mathrm{~V}$ を示した ため, 電源電左計を用い約 1 力月間連続的に測 定を行ったが，105V 前後で安定し正常であっ た。

次に，電源に発生していたノイズが原因であ ると考え, パワーラインモニターを瞬時特別非 常用電源に接続し, 電源電圧変動 $100 \pm 10 \mathrm{~V}$ 以 上, インパル $150 \mathrm{~V}$ 以上, 周波変動 $0.5 \mathrm{~Hz}$ 以上の状態を 20 日間測定した. 電源電生の変動 は全く記録されなかったが，インパルスは患児 入室時に常に記録され，多いときには 1 秒間に 21 個を数えた。また，周波数変動は最大 +2.1 $\mathrm{Hz}$ の変化を示した. そこで, パワーラインモ ニターを接続した状態で, 異常加温の再現を試 みたところ異常加温が起こった。しかし，パワ ーラインモニターは全く異常を示さず，この結 果, パワーラインモニターでは感知できない電 源ノイズによる可能性が考えられた。

その後,オシロスコープによる電源波形の観 察を数回試みたが異常加温が再現しなかったた

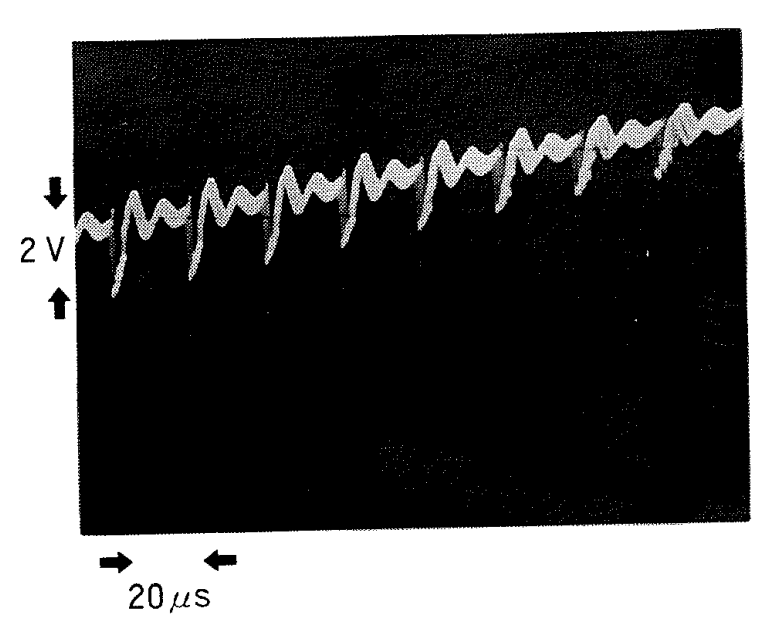

図 3 商用交流に混入した高周波（接地回路, シリンジポンプ接続，一部拡大）

め原因追求には至らなかった。

\section{原因追求 II}

異常加温の原因判明のきっかけは，1台のシ リンジポンプの漏れ電流によるアイソレーショ ン警報の作動であった。

シリンジポンプがアイソレーション警報を作 動させた原因は, シリンジポンプの電源として 使用していたスイッチングレギュレーター内部 のコンデンサーが破損し，図 3 （接地回路にお いて）に示すよらな約 $140 \mathrm{kHz}$ の高周波ノイズ を発生させ，漏れ電流として流れていたためで あった.このシリンジポンプは C F 型で， $2 \mathrm{P}$ コンセントを使用したアース端子を全く持って いない機器であり, 発生した高周波ノイズは電 源ラインを通じて流れていた。

このシリンジポンプの高周波ノイズと今回の 異常加温の関係について検討を行った。なお, この実験は同現象が発生したＣＣＵにて忠児の 入室していない状態で行い，また，電源には実 験に使用するME機器のみを接続した。

1) 接地回路（一般電源）

接地回路である一般電源では図 3 に示すよう な高周波が混入していたが，異常加温は再現し なかった，接地回路では，電源のニュートラル ラインとアースラインは同電位 $(0 \mathrm{~V})$ となるた め, ニュートラルラインから逃げた高周波ノイ ズはアースラインを伝わって逃げるため, 加温 加湿器には影響しなかったと考学られる。

2 ) 非接地回路 I（瞬時特別非常用電源） 


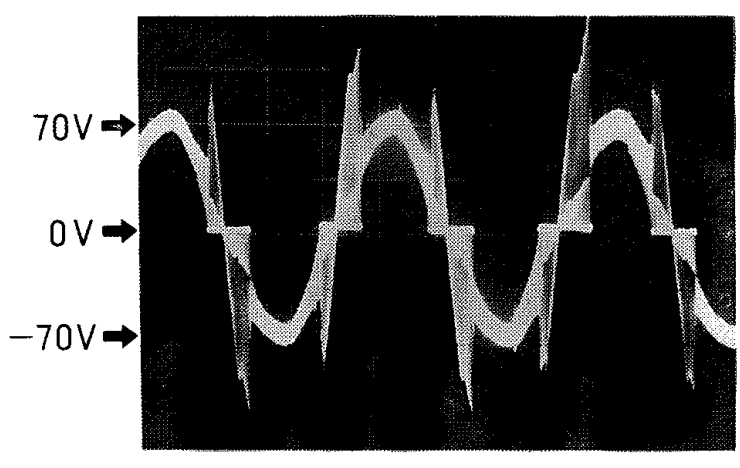

図 4 スパイク状ノイズの混入した商用交流 (排接地回路, シリンジポンプ接続)

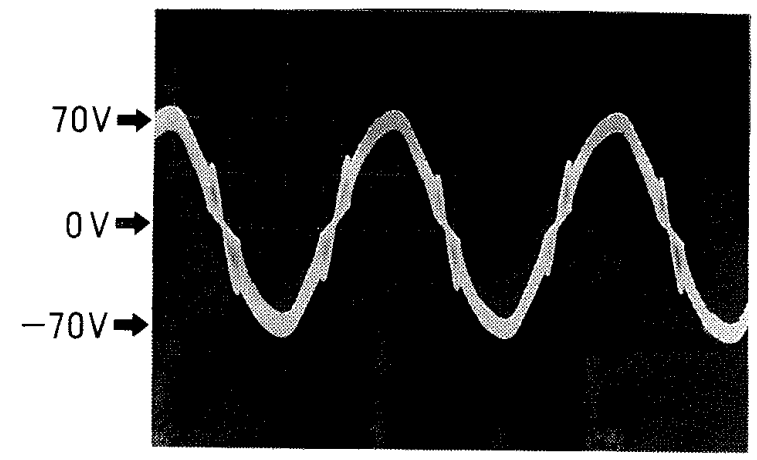

図 5 加温加湿器異常加温時の商用交流（非 接地回路, シリンジポンプ+加温加湿 器接続)

非接地回路である瞬時特別非常用電源では動 作直後から温度上昇が起こり, 異常加温が再現 した.シリンジポンプのみを接続したときの非 接地回路の電源波形は，接地回路で示した高周 波ノイズとは異なり，正弦波のゼロ電位の部分 を中心とした，スパイク状の $\mathrm{P}-\mathrm{P}$ で $260 \mathrm{~V}$ の 異常波形を示した（図4）.しかし，テスター にて電源電王を測定すると $106 \mathrm{~V}$ と正常值を示 した. $139 \mathrm{~V}$ の電生を示したテスターはアナロ グ式のものであり，このノイズを疑似的に測定 していたと考えられた.シリンジポンプがアー スを持たないために，高周波ノイズは電源ライ ンいわゆる正弦波上に直接混入する。瞬時特別 非常用電源の電源ラインはアースに対して浮い た状態にあるため, 混入した高周波ノイズがア ースに逃げることができず，非接地回路を構成 する絶縁トランスを通過する際に，絶縁トラン ス（コイル）には高周波が流れると逆起電力が 発生する性質があるため1，高周波がスパイク 状のノイズに変化したと考えられる。スパイク

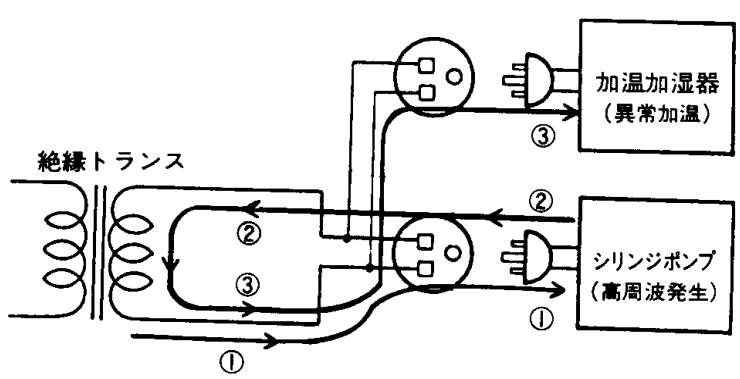

(1)正常雪源波形

(2)高周波混入電源波形

(3)スパイク状龟源波形

図 6 異常加温時の電流波形の流れ

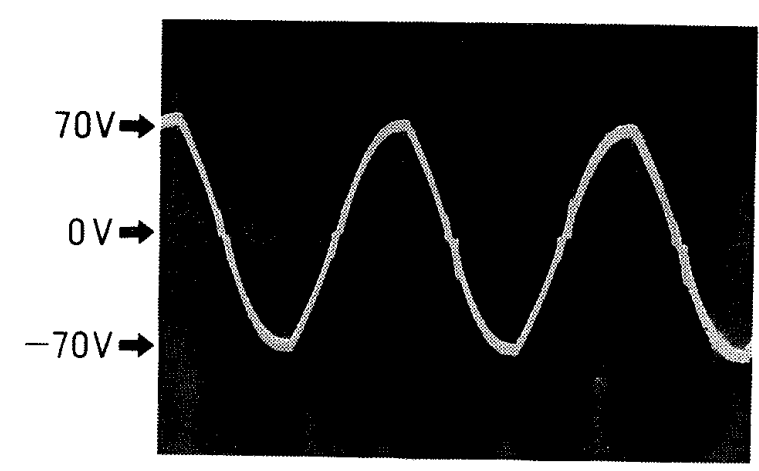

図 7 異常加温停止時の商用交流（非接地回 路，シリンジポンプ+加温加湿器+除 細動装置接続)

状ノイズが混入した状態に加温加湿器を接続す るとノイズは軽減し(図 5 ), 加温加湿器がこ のノイズを取り入れてしまら形となり，ノイズ フィルターの役目を果たしてしまった。そして， 加温加湿器がヒーターの ON/OFF 制御に電源 波形（正弦波）を利用していたために，このス パイク状ノイズが影響し䛊動作となったと考え られる。

図 6 の模式図にて説明すると，(1)の正常な電 源波形がシリンジポンプに供給されると，(2)の 高周波が電源波形に混入した状態（図 3) で絶 縁トランスに戻るかたちとなる。(2)の高周波が 絶縁トランスを通過する際に逆起電力を発生さ せ，(3)のスパイク状ノイズ（図 4) となり，こ れが加温加湿器に流れると異常加温が起こると 考觉られる。

3）非接地回路 II（一般非常用電源）

3 回目の異常加温時に, 現象が停止した一般 非常用電源においても異常加温は再現した。電 源波形もほ辛同様であった。では何故臨床にお 


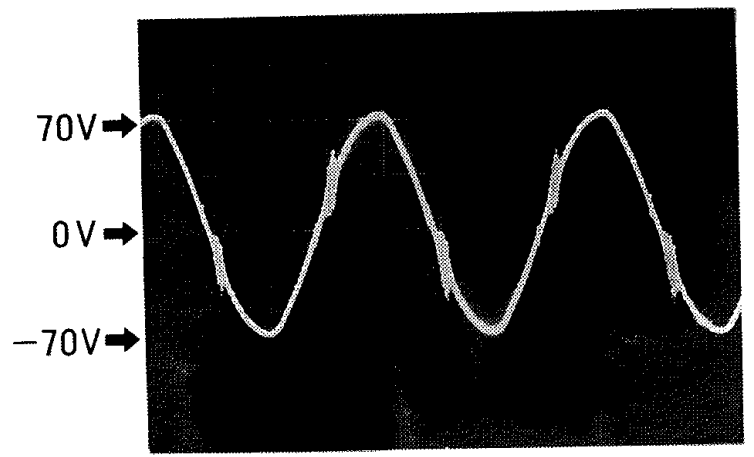

図 8 シリンジポンプノイズフィルター插入 時の商用交流（非接地回路, シリンジ ポンプ接続)

いて一般非常用電源では，異常加温が起きなか ったかであるが，実験において異常加温状態に 除細動装圆を接続したところ，除細動装置が， イズフィルターの役目をしたためにスパイク状 ノイズは軽減し（図 7 ）異常加温は停止した. 当センターの CCU のコンセントの数は 1 ベッ ド当たり瞬時特別非常用電源が 2 個であるのに 対し，一般非常用電源は，8個と多く，使用さ れるME機器も多い。このため, 一般非常用電 源ではノイズフィルターの役目をするME機器 が多くなり高周波ノイズ・スパイク状ノイズが 軽減され，異常加温が発生しなかったと考えら れる. 瞬時特別非常用電源は，基本的に生命維 持管理装置，CCU では人工呼吸器に接続され， 他のME機器は接続しないことが原則になって いるが，CCU と言ら特殊な条件下であり多数 のME機器が使用され，コンセントの数が不足 し, 瞬時特別非常用電源にも一般のME機器も 接続され，今回のようなトラブルに陥ったと考 えられる.

\section{対 策}

今回の異常加温に対し，シリンジポンプの製 造メーカーに拈いて，シリンジポンプにノイズ フィルターを㧴入する対策を実施した。高周波 ノイズはノイズフィルターにより, 若干のノイ ズは混入するものの，スパイク状ノイズはなく なり（図 8)，この結果，異常加温は起こらな くなった。

\section{考察}

人工呼吸器を使用する際に併用される加温加 湿器は，水を暖めることにより加温・加湿する 方法が多く，安全性が十分に整っていることが 重要である.しかし，1992年に電源電圧の低下 による加温加湿器の異常加温が報告されてい る3).

当センターの加温加湿器には, 設定温度に対 し $\pm 2{ }^{\circ} \mathrm{C}$ を超えると警報が作動する構造もち， 異常加温時にもこの過温警報が作動していた。 普通はこの過温警報が作動すればヒーターが OF Fになるはずであるが，スパイク状ノイズ は常にヒーターをＯN状態にするトラブルを起 こしてしまった。また，この加温加湿器のヒー タープレートの下には，ヒーター温度が約 100 ${ }^{\circ} \mathrm{C}$ を超えると機械的に電源を切る部品が取り 付けられていたが，この安全機構も全く作動し なかった. 今回のよらな異常加温を防ぐために は，口元温度が $40^{\circ} \mathrm{C}$ 以上となる場合には，完 全に電源を切ってしまうよらな構造が必要であ りまたノイズ対策も重要である.今回の異常 加温の対策として, 加温加湿器にノイズフィル ターを挿入したが，スパイク状に変化したノイ ズに対しては全く効果がなかった.

異常加温の原因となったシリンジポンプのス イッチングレギュレーターの故障は，1988年製 のもので同時期に購入した 4 台中 2 台に故障が 発見された。故障に至った期間は異常加温の発 生状況から判断し, 購入後 1 年半〜 2 年の間で 比較的早期に起こっていた．その後同タイプの シリンジポンプを55台購入しているが，スイッ チングレギュレーターの故障は起こっていない ことから，1988年製のスイッチングレギュレー ターに問題があったと考えられる。

シリンジポンプが発生したノイズによるトラ ブルの報告は現在までされていないが，逆に電 気メスのノイズによってシリンジポンプの誤動 作したといら報告はある3゙.このよらなことか ら，シリンジポンプのノイズ対策（出さない, 受けない）は必要不可欠である。またこのシ リンジポンプは $2 \mathrm{P}$ コンントタイプであった が，むしアースを持った機器であれば，発生し 
たノイズはアースに逃げることとなり，異常加 温は起こらなかったと考えられる。また，比較 的安易に使用されている一般の電気製品である 電気毛布などは $2 \mathrm{P}$ コンセントであり，ノイズ を発生するため今回のような異常加温を起こす 叮能性もあり, 従って, 病院内で使用される $\mathrm{E}$ 機器を含生電気機器はすべて $3 \mathrm{P}$ 方式にすべ きである。

病陵内の電気ノイズによるトラブルの郝售は 数多くある ${ }^{4 \sim 6)}$ が，今回のような，ME機器か ら発生したノイズが值接他の $\mathrm{ME}$ 機器に影響を 及ぼすのではなく, 非接地回路を通過する際に 変化したノイズが影響を及ぼした報告はない。 非接地回路は地絡事故の際にも電源供給を確保 するためのものであり7)，手術室や ICU では 一般的に使用されている。しかし，今回のよう なトラブルが発生していることから，非接地回 路でのME機器が受ける影響に対しても考㤫す べきである。

\section{まとめ}

加温加湿器の過温警嘏が作動しているにもか かわらず， 1 元温度が $60^{\circ} \mathrm{C}$ にも上㘶する買常 加㳑が起こった：この原因は，シリンジホンフ のスイッチングレギュレーターの故障によって 発生した高周波，イズが，值接電源ラインに沘 入し，非接地回路を桠成する絶縁トランスを通 過する際にスパイク状ノイズに変化し，加温加
湿器がヒーター制御に電溵波形を用いていたた めに，影響を受けたと考えられる。

今後, $\mathrm{ME}$ 機器のノイズ対策は必要不听欠で あり，非嫁地回路と言う特殊条件でのノイズ対 策も必要である。また，非接地回路で使用され るME機器は, 必ず $3 \mathrm{P}$ コンセント方式にする 必要がある。

なお，本淪文の要旨は第69回日本炎科器械学 会大会（東京，1994．5）に沶いて発表した。

\section{文献}

1) 平井紀光：コイルとその働き(2)，クリニカルエ ンジニアリング, 1(6):479-483，1990.

2）飯島光雄：あんな故障こんなトラブル一電源電 圧の変動-..., クリニカルェンジニアリング， 3 (3) : 192-194, 1992.

3））高橋 巨他：電気メ又使用による微量注人器 の高動作に関寸る検討，臨床麻醉 $14(9) ： 1248$ $-1252,1990$.

4）小野哲章：病因と䉓気ノイズクリニカルエン ジニアリング, $3(11): 760-765,1992$.

5）小野哲章：電気メスはノイズの王様，クリ二カ ルエンジニアリング, 3 (11) : 775-783, 1992.

6) 加納 隆：I C U ・病室に打㤝䉓気ノイズ, 病院設備, 28 (5)：405-410, 1986.

7）小野哲章：病院電気設满関係の JIS の読又方・ 考方方，クリニカルエンジニアリング, 2 (12): 723-728, 1991. 